\title{
Wood-decay fungi (Agaricomycetes, Basidiomycota) in three physiognomies in the Savannah region in Brazil ${ }^{1}$
}

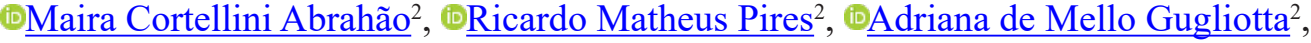 \\ -Eduardo Pereira Cabral Gomes ${ }^{2}$ and $\underline{\text { Vera Lucia Ramos Bononi }}^{2,3,4}$
}

Received: 27 July 2018; accepted: 18 February 2019

How to cite: Abrahão, M.C., Pires, R.M., Gugliotta, A.M., Gomes, E.P.C. \& Bononi, V.L.R. 2019. Wood-decay fungi (Agaricomycetes, Basidiomycota) in three physiognomies in the savannah region in Brazil. Hoehnea 46: e692018. http://dx.doi.org/10.1590/2236-8906-69/2018.

\begin{abstract}
Wood-decay fungi (Agaricomycetes, Basidiomycota) in three physiognomies in the Savannah region in Brazil). This study was carried out aiming at determining whether the following factors are related to the diversity of wooddecay fungi: cerrado physiognomies, vegetation diversity (availability of substrates), preservation status of the area and its management backgrounds, and the existence of rivers nearby (humidity). 796 specimens were collected in four areas: one in the cerrado sensu stricto, one in the semi-deciduous forest and two in the riparian forest (one more preserved and the other less preserved). A total of 92 species of fungi were identified. Eleven species are common in the four areas sampled and 30 species occurred only once during the two-year sampling. Higher richness and abundance were observed in the more preserved area of riparian forest. This study showed that in the same macroclimate, the Agaricomycetes diversity is influenced by the vegetation's physiognomy and diversity related to the soil characteristics, humidity, and conservation level of the area. Keywords: Cerrado, fungal community, ligninolytic fungi, riparian forest, semi-deciduous forest
\end{abstract}

RESUMO - (Fungos decompositores de madeira (Agaricomycetes, Basidiomycota) em três fisionomias no Cerrado do Brazil). Este estudo foi realizado visando Cerrado do Brasil). Visando entender se há correlações entre fisionomia e diversidade da vegetação (disponibilidade de substratos), grau de preservação, história de manejo da área e a proximidade de cursos de água com a diversidade de fungos decompositores de madeira. 796 espécimes foram coletados em quatro áreas: uma no cerrado sensu stricto, uma na floresta estacional semidecidual e duas de floresta ripária (mais e menos preservada). Do total de 92 espécies de fungos, onze são comuns a todas as áreas amostradas e 30 ocorreram uma única vez. Maiores riqueza e abundância de Agaricomicetos foram observadas na floresta ripária mais preservada. Este estudo mostrou que, sob o mesmo macroclima, a diversidade de Agaricomycetes é influenciada por fatores como fisionomia e diversidade da vegetação determinadas pelo tipo de solo, umidade e grau de preservação da área.

Palavras-chave: Cerrado, floresta estacional semidecidual, fungos lignolíticos, mata ciliar, micota

\section{Introduction}

Wood-inhabiting Agaricomycetes has an enzymatic system with extracellular activity to degrade complex structural materials, such as lignin, wood cellulose and hemicellulose, which makes them a group of great ecological value for recycling nutrients in ecosystems (Gilbertson 1980, Alexopoulos et al. 1996, Lundell et al. 2010). The total diversity of fungi is estimated to range from 0.7 to 5.1 million species (Blackwell 2011, Hawksworth \& Lücking 2017), but so far only about $1.9 \%$ (97,330 species) have been described. A total of 538 genera and 6,384 species of wood-decay Agaricomycetes are known worldwide (Kirk et al. 2008).

1. Parte da Tese de Doutorado do primeiro Autor

2. Instituto de Botânica, Av. Miguel Stéfano, 3687, 04045-972 São Paulo, SP, Brasil

3. Universidade Anhanguera/Uniderp, Rua Ceará, 333, 79003-010 Campo Grande, MS, Brasil

4. Corresponding author: vbononi@uol.com.br 
The Cerrado is the second largest area in Brazil (21\% of the Brazilian territory, around 1.8 to 2.0 million $\mathrm{km}^{2}$ ), after the Amazon Forest (IBGE 2004, Coutinho 2016). Studies regarding Agaricomycetes focused on taxonomy mention the occurrence of 134 species (Sampaio 1916, Fidalgo et al., 1965, Bononi 1984, Gugliotta 1997, Baseia \& Milanez 2001a, b, 2002a, b, 2003, Baseia 2005, Baseia et al. 2007, Abrahão et al. 2012, Alvarenga et al. 2015, CostaRezende et al. 2015). None of these authors present ecological relations between fungi diversity and the "cerrado" physiognomies sensu stricto.

The general term "Cerrado" has been used to designate savannah-type vegetation with a gradient of physiognomies, from the grassland (clean field) to dense forest with 15 to $18 \mathrm{~m}$ high vegetation ("cerradão"), and between those, there are some intermediate physiognomies. Forests or woods in the "Cerrado" Biome near watercourses are riparian forests which correspond to about $5 \%$ of the Cerrado area (Pivello \& Coutinho 1996). But within the "Cerrado" Biome, patches of other vegetation physiognomies may occur interspersed among the cerrado forms, determined mainly by edaphic and geomorphological features, and semi-deciduous forests, which can be found in richer soils, with more water available and they correspond to about $15 \%$ of the "Cerrado" area. Gallery forests present more diversity than those in the Cerrado areas. There are Cerrado-preferred species, and exclusively semi-deciduous forests species and there are common species in all ecosystems (Eiten 1994, Pereira et al. 2011).

Satellite data showed that $55 \%$ of the Cerrado had been cleared or modified, mainly for setting up pastures and agricultural fields (Klink \& Machado 2005).

Considering the importance of wood-decay Agaricomycetes in the maintenance of ecosystems and the shortage of studies (Seibold et al. 2015), this study aimed at understanding whether there is any correlation between the diversity of wood-decay fungi and the following factors: "cerrado" physiognomies, vegetation diversity (availability of substrates), area preservation status and its management background and existence of rivers nearby (humidity).

\section{Material and methods}

Study area - The Mogi-Guaçu Biological Reserve $\left(22^{\circ} 11^{\prime}-22^{\circ} 16^{\prime} \mathrm{S}, 47^{\circ} 08^{\prime}-47^{\circ} 11^{\prime} \mathrm{W}\right)$ is composed by two areas (A and B), located in the municipality of Mogi-Guaçu, São Paulo State (figure 1). In this region, the Cerrado vegetation almost reaches its austral limit (Klink \& Machado 2005). Altitudes vary from 590 to $650 \mathrm{~m}$; the predominant climate is Aw with rainy summers and dry winters according to the classification of Köppen-Geiger (Peel et al. 2007). The soil is classified as sandy, acidic, poor in organic matter and oligotrophic (Giudice-Neto 2010). Soil abiotic factors in areas $\mathrm{A}$ and $\mathrm{B}$ during the rainy and dry seasons are presented by (Nascimento et al. 2012).

The areas studied (areas A and B) cover a total area of 470 ha and they have not been disturbed by fire for the last 30 years. The surroundings of both areas are mostly agricultural production units, showing diversified cultures of eucalyptus, cassava, sugar cane, corn, and oranges. The riparian forest is associated with the Mogi-Guaçu River and streams. A description of the particularities of the areas can
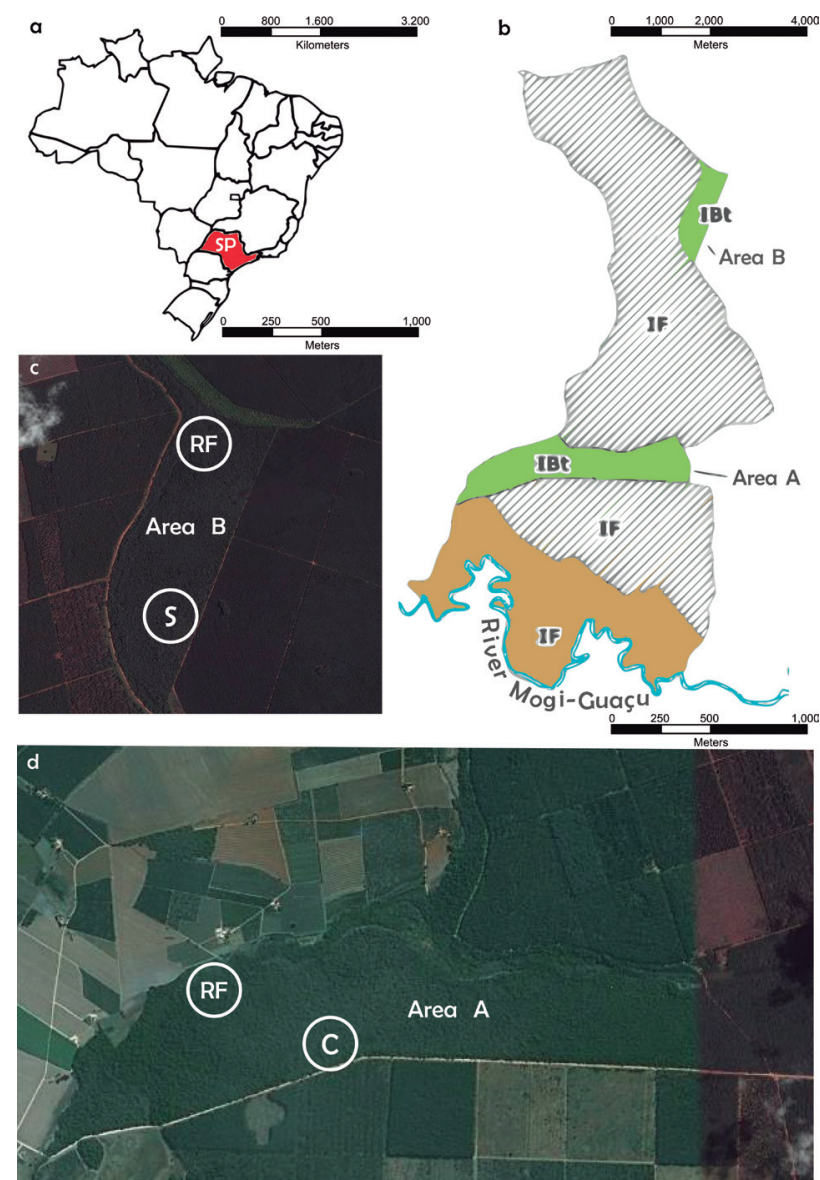

Figure 1. a. Location of the studied areas in the Mogi-Guaçu Biological Reserve (IBt), São Paulo State, Brazil. b. Mogi-Guaçu Biological Reserve (IBt: Conservation Area of the Instituto de Botânica, IF: Conservation Area of the Instituto Florestal). c. Satellite image of Area B (C: Cerrado; S: Semi-deciduous Forest; RF: Riparian Forest). d. Satellite image of Area A. (Modified from Giudice-Neto, 2010). 
be found in Giudice-Neto (2010). Four areas were sampled: one in the cerrado sensu stricto, one in the semi-deciduous forest and two in the riparian forest (one more preserved and the other less preserved).

Area A, covering 343.42 ha, is composed of "Cerrado" vegetation at a medium stage of regeneration. According to Mantovani \& Martins (1993), this area has been used for cattle grazing and logging.

Area B, covers 126.63 ha, with a semi-deciduous forest. The original forest is in good conditions (no exotic species, large gaps or herbaceous climbers). However, in some areas (mainly in the center), there are trees of around $15 \mathrm{~m}$ high and the herbaceous layer shows a high grass density.

Fungi sampling - Considering the recommendations of Zak \& Willig (2004) and a preliminary study conducted by Abrahão et al. (2010), sample sets were placed randomly at 10 transects of $4 \times 50 \mathrm{~m}$ in the riparian forest in area $\mathrm{A}$ (A_RF) and area $B$ (B_RF), in the Cerrado vegetation in area $A$ (A_C) and semi-deciduous forest in area B (B_S). The entries of the transects were georeferenced. Basidiomata were collected bimonthly at those transects from August/2009 to June/2011, totaling 12 field expeditions covering all seasons. Agaricales was excluded from this study due to their ephemeral basidiomata, which requires a different methodology.

Species identification was based on observation and analysis of basidioma macro- and microscopic characteristics (Ryvarden 1991, Teixeira 1993, 1994, 1995). Evidence for dextrinoid and amyloid reactions was tested in Melzer's reagent (Gilbertson \& Ryvarden 1986, Gugliotta \& Bononi 1999). Preservation and herborization of specimens were performed according to Fidalgo \& Bononi (1984). Vouchers for every species were deposited at the SP Herbarium of the Instituto de Botânica (SP).

The species recorded over 15 times in all areas during the study were considered common species, while species recorded less than five times were considered rare and a species recorded between 5 and 15 times, an occasional species (Dai 2012).

Statistical analysis - To compare species richness between the sample sets (A_C, B_S, A_RF, B_RF), an estimate was made by rarefaction with a confidence interval of $95 \%$ to account for differences in the sampling effort.

Diversity was assessed by profile diversity, which allows simultaneous evaluation of richness and abundance of every species with different weights in different diversity indices. The profile is derived from the Renyi's general formula, the Renyi index (Tóthmérész 1995). When alpha $=0$, this function provides the total number of the species richness. For alpha $=1$, the index is proportional to the Shannon index, whereas, for alpha $=2$, the index behaves like the Simpson index assigning higher weight and relative abundance of species. The profile is represented in an alpha vs. values graph to which a curve is added, allowing checking the indices simultaneously.

The sampling units were organized according to the principal coordinate's analysis ( $\mathrm{PCoA})$ to evaluate their relations in the ordering space from the distance matrix among the sampling units, using the Jaccard similarity index. Due to the sensitivity of the method to matrices with many zeros, species with a single record were excluded from the analysis.

For comparisons among groups for all transects, plant communities and area were used as grouping variables; the similarity analysis permutation test was applied (ANOSIM, Clarke \& Warwick 1994) using the Bray-Curtis dissimilarity matrix. Analyses were performed with PAST software version $2.17 \mathrm{c}$ with 9,999 permutations for ANOSIM (Hammer et al. 2001).

\section{Results and Discussion}

A total of 796 specimens of 92 species were collected throughout the study.

Higher richness and abundance were observed at area B (71 species, 503 specimens), including semideciduous forest and riparian forest. In the area A 54 species, 293 specimens were found, including Cerrado and riparian forest. Many species $(38 ; 41.3 \%)$ were exclusive to area B and 21 species $(38.89 \%)$ were exclusive to area $\mathrm{A}$ and 18 species were exclusive to the Cerrado and 31, to the riparian forest (table 1).

Considering all areas, the group sample B_RF showed 272 specimens (34.17\%), followed by $\bar{B}$ _S (231 specimens, 29.02\%), A_C (155 specimens, 19.47\%) and A_RF (138 specimens, 17.34\%) (table 1). Eleven species are common in the four areas sampled and 30 species occurred only once during the two-year sampling.

Sampling groups showed a significant difference in composition, except for A_C and A_RF (table 2, ANOSIM, "mean rank within" 271.6; "mean rank between" 426.2; $\mathrm{p}<0.05$ ).

In the richness-based ordination analysis (figure 2), the two axes explained $23.75 \%$ of the 
Table 1. Wood-decay Agaricomycetes collected in areas A and B in the Mogi-Guaçu Biological Reserve, SP. A_C: relative abundance in Cerrado transections of area A, A RF: relative abundance on transections of Riparian Forest in area A, A: abundance in area A, B_S: relative abundance of transections in Semideciduous Forest of area B, B_RF: relative abundance of transections in the Riparian Forest of area B, B: abundance in area B, T: total abundance.

\begin{tabular}{|c|c|c|c|c|c|c|c|}
\hline Species & A_C & A_RF & $\mathrm{A}$ & B_S & B_RF & $\mathrm{B}$ & $\mathrm{T}$ \\
\hline Fuscoporia gilva & 11 & 8 & 19 & 39 & 21 & 60 & 79 \\
\hline Pycnoporus sanguineus & 26 & 27 & 53 & 2 & 11 & 13 & 66 \\
\hline Tyromyces duracinus & 2 & - & 2 & 37 & 15 & 52 & 54 \\
\hline Fomitiporia maxonii & 20 & 6 & 26 & 16 & 4 & 20 & 46 \\
\hline Polyporus guianensis & - & - & 0 & 29 & 12 & 41 & 41 \\
\hline Trametes villosa & 6 & 10 & 16 & 4 & 20 & 24 & 40 \\
\hline Coriolopsis floccosa & 7 & 12 & 19 & 12 & 7 & 19 & 38 \\
\hline Hymenochaete tenuis & 8 & 7 & 15 & 10 & 8 & 18 & 33 \\
\hline Schizophyllum commune & 7 & 10 & 17 & - & 8 & 8 & 25 \\
\hline Dichomitus setulosus & 5 & 7 & 12 & 7 & 1 & 8 & 20 \\
\hline Perenniporia ochroleuca & 7 & 3 & 10 & 5 & 1 & 6 & 16 \\
\hline Chondrostereum purpureum & 5 & 2 & 7 & 4 & 4 & 8 & 15 \\
\hline Lentinus crinitus & 6 & 4 & 10 & 1 & 4 & 5 & 15 \\
\hline Hymenochaete digitata & 3 & 4 & 7 & 1 & 5 & 6 & 13 \\
\hline Polyporus tenuiculus & - & - & 0 & 6 & 7 & 13 & 13 \\
\hline Coriolopsis caperata & - & - & 0 & 1 & 11 & 12 & 12 \\
\hline Echinoporia aculeifera & - & 2 & 2 & 1 & 9 & 10 & 12 \\
\hline Schizopora paradoxa & 3 & - & 3 & 4 & 5 & 9 & 12 \\
\hline Stereum ostrea & 1 & - & 1 & 3 & 7 & 10 & 11 \\
\hline Gloeoporus thelephoroides & - & - & 0 & 6 & 4 & 10 & 10 \\
\hline Pachykytospora alabamae & 2 & 6 & 8 & 1 & 1 & 2 & 10 \\
\hline Polyporus leprieurii & - & - & 0 & 4 & 6 & 10 & 10 \\
\hline Schizophyllum umbrinum & - & 4 & 4 & - & 5 & 5 & 9 \\
\hline Aleurodiscus cerussatus & 3 & 2 & 5 & 3 & - & 3 & 8 \\
\hline Grammothele subargentea & 2 & 3 & 5 & 2 & 1 & 3 & 8 \\
\hline Hexagonia variegata & - & - & 0 & 6 & 2 & 8 & 8 \\
\hline Hydnopolyporus fimbriatus & - & - & 0 & - & 8 & 8 & 8 \\
\hline Hymenochaete damicornis & 3 & - & 3 & - & 5 & 5 & 8 \\
\hline Podoscypha ravenelii & - & - & 0 & - & 8 & 8 & 8 \\
\hline Scopuloides rimosa & 2 & - & 2 & - & 6 & 6 & 8 \\
\hline Phylloporia chrysites & - & - & 0 & - & 7 & 7 & 7 \\
\hline Schizopora flavipora & 2 & - & 2 & 4 & 1 & 5 & 7 \\
\hline Hymenochaete rheicolor & 1 & 3 & 4 & 2 & - & 2 & 6 \\
\hline Mycobonia flava & - & - & 0 & 1 & 5 & 6 & 6 \\
\hline Polyporus dictyopus & - & - & 0 & 1 & 5 & 6 & 6 \\
\hline Dichomitus cavernulosus & 2 & - & 2 & 2 & 1 & 3 & 5 \\
\hline Pachykytospora papyracea & - & 1 & 1 & 2 & 2 & 4 & 5 \\
\hline Datronia mollis & - & - & 0 & - & 4 & 4 & 4 \\
\hline Irpex lacteus & - & 2 & 2 & - & 2 & 2 & 4 \\
\hline Polyporus ciliatus & - & - & 0 & - & 4 & 4 & 4 \\
\hline
\end{tabular}


Table 1 (continuation)

\begin{tabular}{|c|c|c|c|c|c|c|c|}
\hline Species & A_C & A_RF & A & B_S & B_RF & $\mathrm{B}$ & $\mathrm{T}$ \\
\hline Tyromyces leucomallus & - & - & 0 & 1 & 3 & 4 & 4 \\
\hline Auricularia polytricha & 1 & 1 & 2 & - & 1 & 1 & 3 \\
\hline Cyclomyces iodinus & - & - & 0 & 3 & - & 3 & 3 \\
\hline Daedalea aethalodes & 3 & - & 3 & - & - & 0 & 3 \\
\hline Fomes fasciatus & - & - & 0 & - & 3 & 3 & 3 \\
\hline Gloeoporus dichrous & - & - & 0 & 3 & - & 3 & 3 \\
\hline Hymenochaete opaca & - & 3 & 3 & - & - & 0 & 3 \\
\hline Hyphoderma sp. 1 & 1 & 2 & 3 & - & - & 0 & 3 \\
\hline Phanerochaete sp. 1 & 1 & - & 1 & - & 2 & 2 & 3 \\
\hline Rigidoporus microporus & - & - & 0 & - & 3 & 3 & 3 \\
\hline Steccherinum sp. 1 & 1 & - & 1 & - & 2 & 2 & 3 \\
\hline Aleurodiscus botryosus & 1 & 1 & 2 & - & - & 0 & 2 \\
\hline Cymatoderma caperatum & - & - & 0 & - & 2 & 2 & 2 \\
\hline Gloeoporus purpurascens & 1 & - & 1 & - & 1 & 1 & 2 \\
\hline Hidnoide sp. 1 & 1 & 1 & 2 & - & - & 0 & 2 \\
\hline Hymenochaete corrugata & - & - & 0 & - & 2 & 2 & 2 \\
\hline Hyphodontia sp. 1 & 1 & - & 1 & 1 & - & 1 & 2 \\
\hline Hyphodontia sp. 2 & 1 & - & 1 & 1 & - & 1 & 2 \\
\hline Phanerochaete aff. sordida & - & - & 0 & - & 2 & 2 & 2 \\
\hline Polyporus tricholoma & - & - & 0 & - & 2 & 2 & 2 \\
\hline Steccherinum reniforme & - & - & 0 & 1 & 1 & 2 & 2 \\
\hline Trichaptum sector & - & - & 0 & - & 2 & 2 & 2 \\
\hline Aleurodiscus exasperatus & 1 & - & 1 & - & - & 0 & 1 \\
\hline Amauroderma praetervisum & - & - & 0 & - & 1 & 1 & 1 \\
\hline Ceriporia spissa & - & 1 & 1 & - & - & 0 & 1 \\
\hline cf. Brevicellicium spp. & 1 & - & 1 & - & - & 0 & 1 \\
\hline Dichostereum cf. sordulentum & - & 1 & 1 & - & - & 0 & 1 \\
\hline Hexagonia hydnoides & - & - & 0 & 1 & - & 1 & 1 \\
\hline Hidnoide sp. 2 & - & - & 0 & - & 1 & 1 & 1 \\
\hline Hidnoide sp. 3 & - & 1 & 1 & - & - & 0 & 1 \\
\hline Hidnoide sp. 4 & - & - & 0 & - & 1 & 1 & 1 \\
\hline Hidnoide sp. 5 & - & - & 0 & - & 1 & 1 & 1 \\
\hline Hymenochaete pinnatifida & 1 & - & 1 & - & - & 0 & 1 \\
\hline Hyphodontia sp. 3 & 1 & - & 1 & - & - & 0 & 1 \\
\hline Hyphodontia sp. 4 & - & - & 0 & 1 & - & 1 & 1 \\
\hline Hyphodontia sp. 5 & - & 1 & 1 & - & - & 0 & 1 \\
\hline Hyphodontia sp. 6 & - & - & 0 & - & 1 & 1 & 1 \\
\hline Merulius sp. 1 & - & - & 0 & 1 & - & 1 & 1 \\
\hline Phanerochaete corymbata & - & 1 & 1 & - & - & 0 & 1 \\
\hline Phanerochaete sp. 2 & 1 & - & 1 & - & - & 0 & 1 \\
\hline Phanerochaete sp. 3 & 1 & - & 1 & - & - & 0 & 1 \\
\hline
\end{tabular}


Table 1 (continuation)

\begin{tabular}{lccccccc}
\hline Species & A_C & A_RF & A & B_S & B_RF & B & T \\
\hline Phanerochaete sp. 4 & 1 & - & 1 & - & - & 0 & 1 \\
Phanerochaete sp. 5 & 1 & - & 1 & - & - & 0 & 1 \\
Phellinus cf. chryseus & - & 1 & 1 & - & - & 0 & 1 \\
Phellinus punctatiformis & - & - & 0 & - & 1 & 1 & 1 \\
Phlebia sp. 1 & 1 & - & 1 & - & - & 0 & 1 \\
Phylloporia spathulata & - & - & 0 & - & 1 & 1 & 1 \\
Rigidoporus lineatus & - & - & 0 & - & 1 & 1 & 1 \\
Scytinostroma duriusculum & - & - & 0 & 1 & - & 1 & 1 \\
Steccherinum sp. 2 & - & 1 & 1 & - & - & 0 & 1 \\
Stereum sp. 1 & - & - & 0 & - & 1 & 1 & 1 \\
Stereum sp. 2 & - & - & 0 & 1 & - & 1 & 1 \\
\hline Total of ocurrences & 155 & 138 & 293 & 231 & 272 & 503 & 796 \\
\hline Total of species & 42 & 32 & 54 & 41 & 60 & 71 & 92 \\
\hline
\end{tabular}

Table 2. Probability of lack of differences from dissimilarity matrix of Bray-Curtis among sampling groups based on species abundance found in Mogi-Guaçu Biological Reserve, SP. Non-parametric similarity analysis of one factor (ANOSIM; 9999 permutations; R: 0.3962; Bonferroni correction). A_C: Cerrado of area A, A_RF: Riparian Forest in area A, B_S: Semideciduous Forest of area B, B_RF: Riparian Forest of area B.

\begin{tabular}{lcccc}
\hline & A_C & A_RF & B_RF & B_S \\
\hline A_C & & 1,0000 & 0,0018 & 0,0006 \\
A_RF & & & 0,0048 & 0,0006 \\
B_RF & & & 0,0024 \\
B_S & & & \\
\hline
\end{tabular}

variation. Axis 1 separated the areas $\mathrm{A}$ and $\mathrm{B}$. The results of ANOSIM showed significant differences between areas (table 2, ANOSIM, "mean rank within" 271.6, "mean rank between" 426.2; $<<0.05)$, except for the two plant communities in area A.

The rarefaction curve of the species (figure 3 ) and the diversity profile diagram (figure 4) showed that the general standard of richness is higher in B_RF, followed by A_C, B_S, and A_RF.

The results of the similarity analysis and ordination showed differences between areas A and $\mathrm{B}$ as well as between different physiognomies. Areas A and B, despite being close to each other and subject to the same macroclimate conditions, differ in several factors such as soil type (Nascimento et al. 2012), vegetation type and factors related to microclimate (Giudice-Neto 2010).

Additionally, areas A and B, although they have not been disturbed by fire for the last 30 years, differ as to their conservation level because they have a different handling background, area $\mathrm{B}$ being more conserved than area $\mathrm{A}$, which was more used in the past for cultivation, wood removal and cattle grazing, and later for research in general (Mantovani \& Martins 1993, Giudice-Neto 2010). So, the riparian forest in area B is more preserved than that in area A, which can explain the more significant diversity of Agaricomycetes in the riparian forest of area B, and little similarity among the riparian areas. In area A, higher values for species richness were recorded for the Cerrado sampling group, probably due to the degradation of the riparian forest.

Lindner et al. (2006) studied the effects of forest management on fungal diversity and found significant differences for the most abundant species, indicating that the history of the site, amount and quality of the substrate and the management of the area are important factors to predict fungi species richness. 


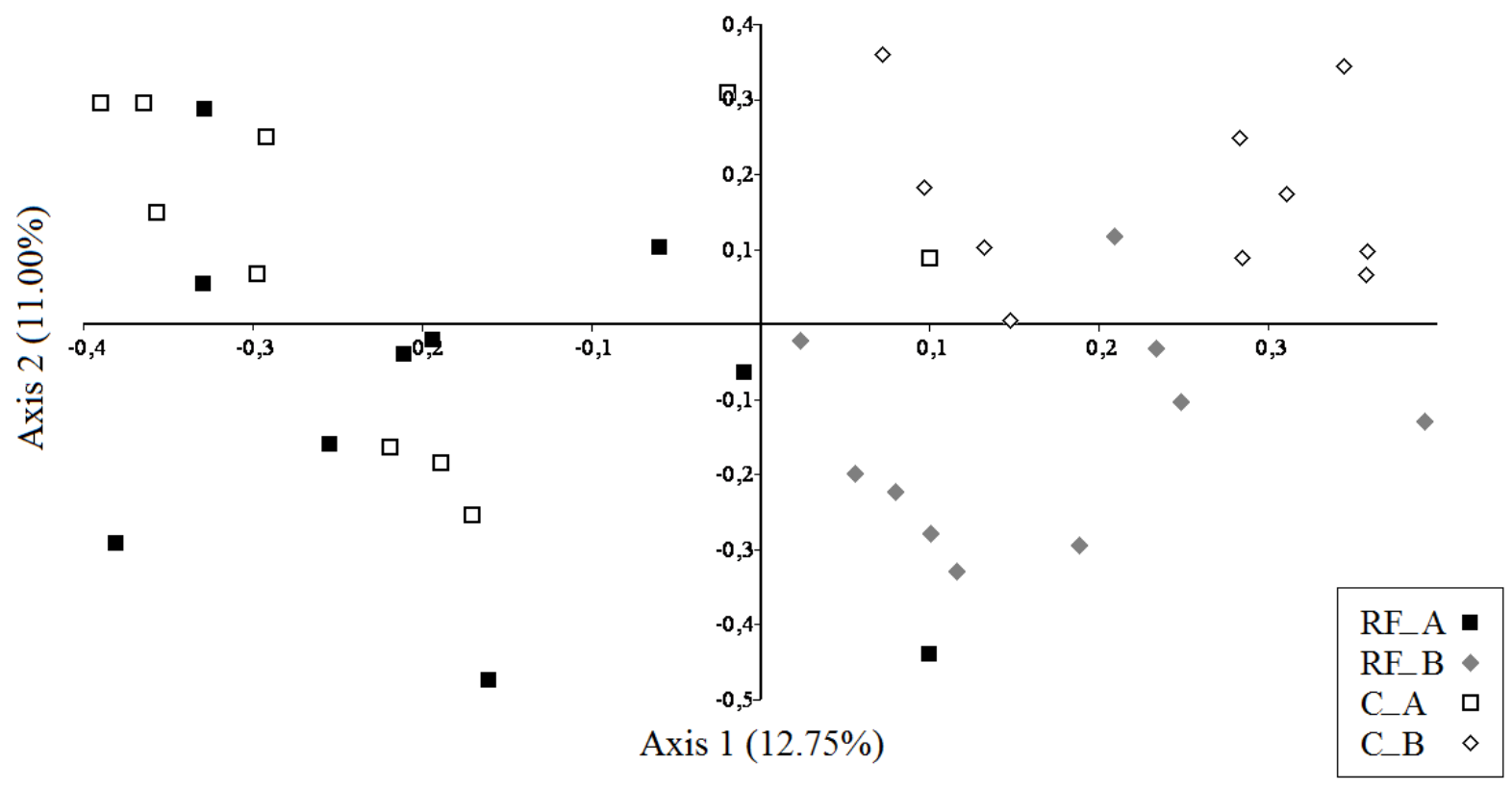

Figure 2. Ordination of 40 samples (transects $4 \times 50 \mathrm{~m}$ ) in Mogi Guaçu Park, SP, Brazil. The scatter diagram is defined by ordination axes 1 and 2 generated by principal coordinates analysis from Jaccard Similarity Matrix. The percentage of total variation represented by the axes is indicated.

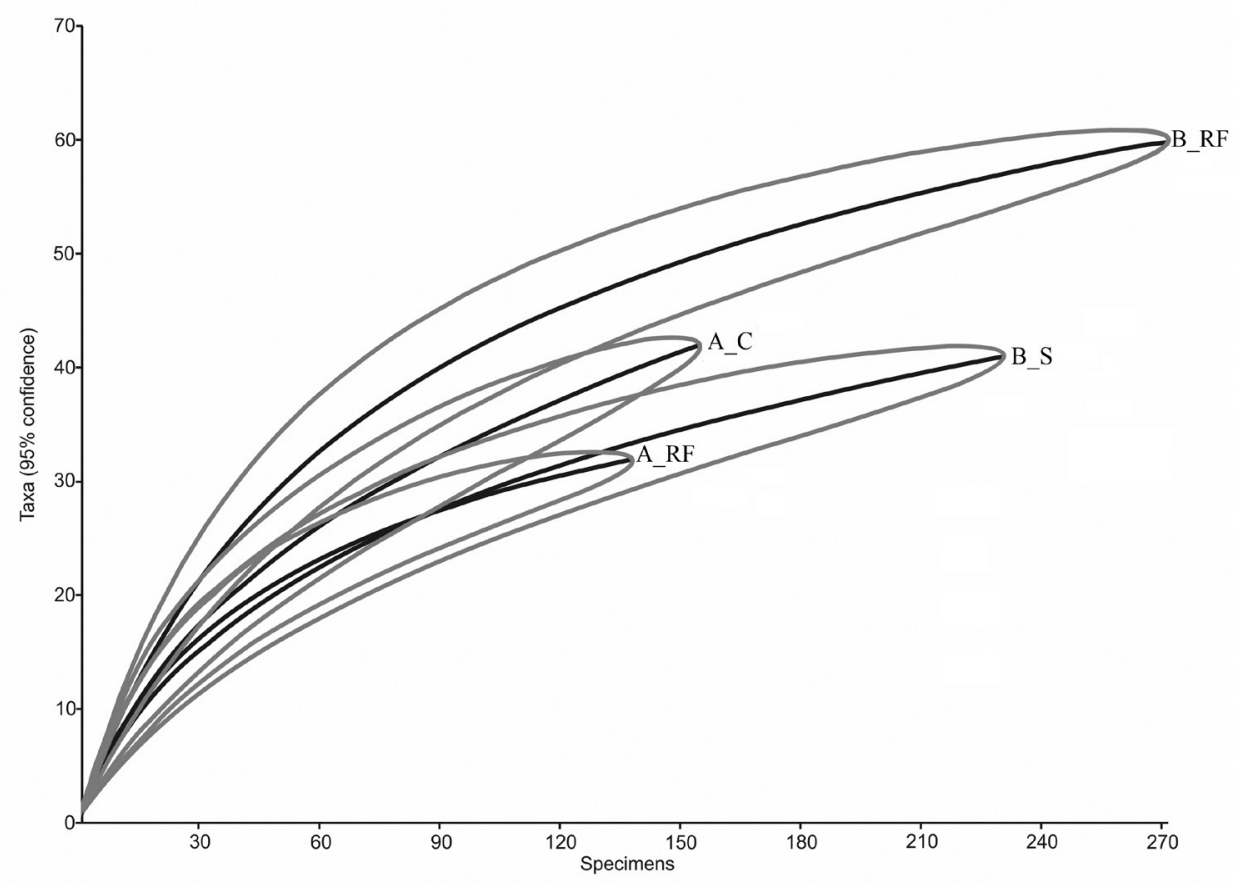

Figure 3. Rarefaction curve of sampling groups observed in the Mogi-Guaçu Biological Reserve, SP. Average of species number (+ confidence interval of $95 \%$ ) for each area in relation to the function of the number of specimens sampled. 


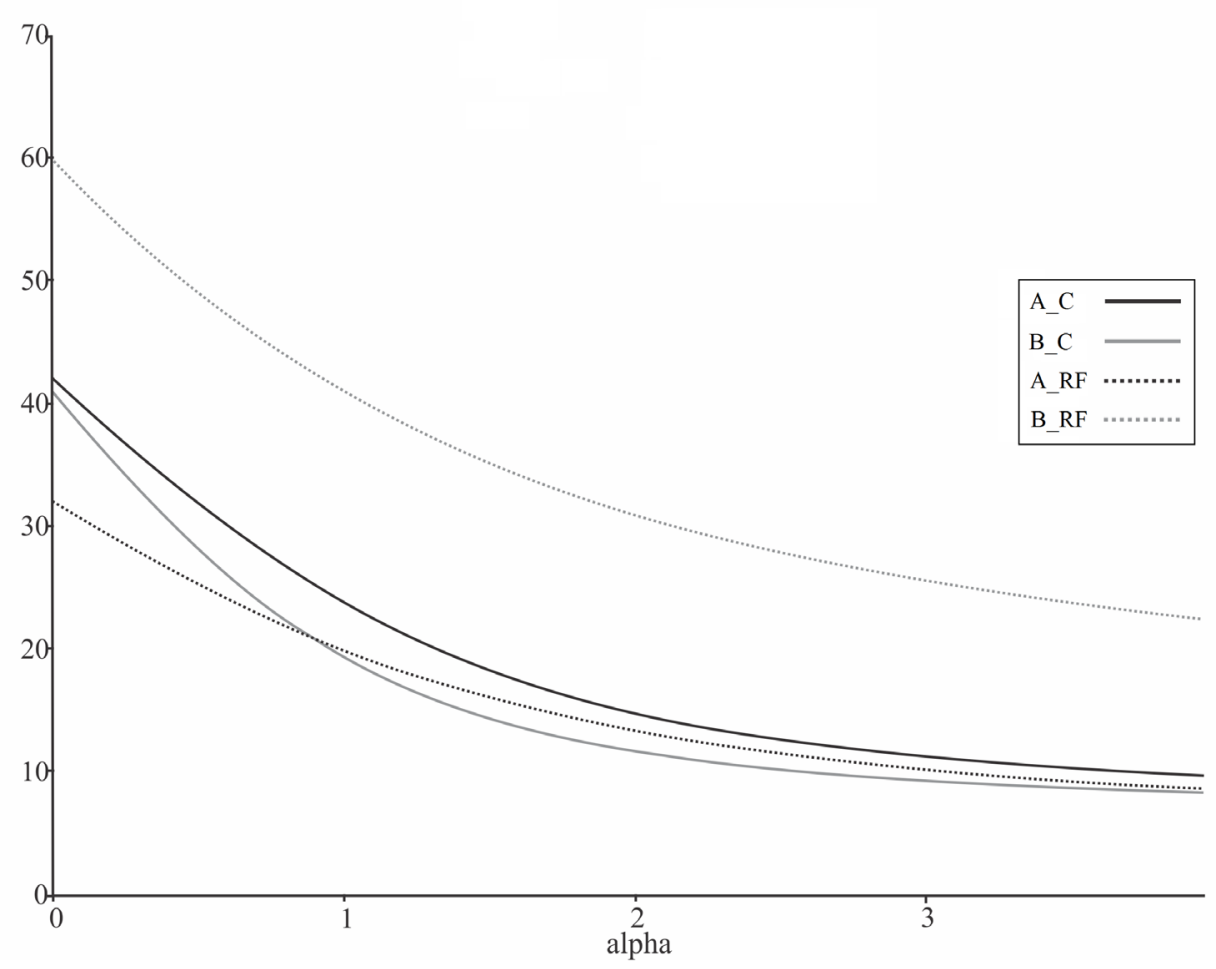

Figure 4. Diversity profile of wood-decay Agaricomycetes community in the Mogi-Guaçu Biological Reserve.

There is only one study in Neotropical region comparing basidiomycete diversity in more and less preserved areas (Gibertoni et al. 2007) conducted in the northeast Atlantic rain forest. They concluded that the number of fungal species is positively affected by the level of conservation of the vegetation. However, the results of Penttilä et al. (2006) for polypores in northern Europe showed that species number, the incidence of occurrence and abundance of the rarest, most threatened and near-threatened species are much lower in old-growth fragments with a long history of intensive forestry. In our study, higher species richness in the riparian forest was expected because most fungi species are susceptible to humidity variations. Papers dealing with vegetation (Pereira et al. 2011) show that more richness and diversity can be found in riparian forests than in other physiognomies in Cerrado areas. Consequently, substrates' diversity there is higher than in non-riparian areas, which eases wood-degrading fungi's growth.

Using next-generation metagenomic sequencing (NGS) and soil physicochemical properties, Araujo et al. (2017) evaluated the fungal diversity across a gradient of vegetation that included Graminoid Field", sensu stricto "Cerrado", "Cerradão", and Deciduous Forest. The results showed that Deciduous Forest presented the highest richness. Agaricomycetes was one of the most abundant classes of fungi found across the gradient of "Cerrado" area in north-eastern Brazil. The contrast in fungal communities between Deciduous Forest and Graminoid Field evidenced the differences in vegetation and soil properties of these sites. The riparian forest was not considered.

According to Castro et al. (2016), who observed a distinction in the fungal communities between Graminoid Field and Riparian Forest from stricto sensu "Cerrado" and "Cerradão", compositions of bacterial, archaeal, and fungal communities in the different vegetation physiognomies were associated with temporal variations of soil moisture.

According to Oliveira-Filho \& Fontes (2000), there is greater floristic similarity at the species level between Atlantic rain and semi-deciduous forests than between any of these and either Amazonian rain forests or Cerrado. Nevertheless, the Cerrado flora was much more closely related to Atlantic semideciduous forests than to the Atlantic rain forests or with Amazonian forests. The results of the similarity analysis and ordination showed that Agaricomycetes diversity of the Cerrado is also much more closely related to semi-deciduous forests.

In Brazil, the only study that evaluated the proportion of common, occasional (or subordinate) 
and rare species of Agaricomycetes was conducted by Borba-Silva et al. (2015) in the Atlantic Forest in Santa Catarina State. Out of 152 specimens, rare polypore species (less than five records) represented $86 \%$ of the total number of species and $50 \%$ of total abundance, and only three species were considered common or dominant $(5.4 \%$ out of all and $26 \%$ of total abundance). In our study, most of the species $(59.78 \%)$ were also considered rare, representing only $12.31 \%$ of total abundance, while eleven species were considered common (11.96\% out of all species and $57.54 \%$ of total abundance). Twenty-six species (28.26\%) were considered occasional, representing $30.15 \%$ of total abundance. The differences found between our findings and those obtained by those authors are probably the different biomes assessed and the sampling size.

When comparing the most abundant species, Fuscoporia gilva, Tyromyces duracinus, and Polyporus guianensis were more frequent in area $\mathrm{B}$, while Pycnoporus sanguineus occurred more often in area A. According to Ryvarden (2004), Fuscoporia gilva is one of the most collected species in tropical regions. According to the Flora Species List of Brazil (Maia et al. 2015), F. gilva is widespread in Brazil and has been recorded in the Cerrado, the Atlantic Forest, the Amazon Forest, "Caatinga" and "Pantanal".

Pycnoporus sanguineus is frequently found in sites exposed to sunlight and with reduced levels of humidity and higher temperatures, being regarded as an indicator of the level of conservation of the areas (Guzmán-Dávalos \& Guzmán 1979, Gibertoni et al. 2007).

The abundance of some species, such as Fuscoporia gilva, Lentinus crinitus and Polyporus guianensis, can be related to the fact they are species complexes, morphologically quite similar species and, as such, it is difficult to identify them with traditional methods. Those complexes are not yet well known and in the future, they can impact on the results of this paper.

Núñez (1996) studied species showing ecological adaptations to different levels of humidity, some species are perennial and produce basidiomata capable to survive water shortage, forming new tubes and fertile layers instead of new basidiomata after every rainy season, such as some species of the genera Deadalea, Fomes and Phellinus s.l. Some annual species, such as Coriolopsis spp., Fuscoporia gilva, and annual species of Hexagonia develop an annual basidioma that remains sterile under low humidity, especially on trails, in canopy gaps and dry habitats, but they sporulate under high humidity in closed and humid canopies or during the rainy season in dry forests. On the other hand, species of Polyporus and Tyromyces are usually dependent on abundant water and are numerous in shaded and humid areas, they produce fleshy basidiomata under suitable conditions, which collapse after sporulating. In our study, Daedalea aethalodes, Fomes fasciatus, Fomitiporia maxonii and Phellinus punctatiformis were more abundant in areas of the Cerrado sensu stricto (drier), Fuscoporia gilva and Coriolopsis floccosa occurred in all sampling groups and Polyporus (exclusive to area "B") and Tyromyces species were much more frequent in area $\mathrm{B}$, where vegetation is more compact and humid.

The riparian forest has higher vegetal diversity then cerrado, it shows Cerrado-preferred species, and common species to riparian, "cerrado" and semideciduous forest (Pereira et al. 2011). The same was found with the Agaricomycetes diversity studied. Under the same macroclimate, the Agaricomycetes diversity is influenced by factors such as the vegetation physiognomies which is related to the soil type, humidity and preservation level of the area.

\section{Acknowledgments}

The authors are grateful to FAPESP for providing a research grant (number 2009/01403-6). This manuscript is a part of the first author's Ph.D. thesis, developed in the "Programa de Pós Graduação em Biodiversidade Vegetal e Meio Ambiente do Instituto de Botânica". We would like to thank the staff of the Mogi-Guaçu Biological Reserve for allowing us to use their facilities.

\section{Literature cited}

Abrahão, M.C., Gomes, E.P.C., Gugliotta, A.M. \& Bononi, V.L.R. 2010. Avaliação do uso de transecções para estudo da estrutura de uma comunidade fúngica no cerrado de Mogi-Guaçu, SP, Brasil. In: Anais do XVIII Congresso da Sociedade Botânica de São Paulo.

Abrahão, M.C., Gugliotta, A.M. \& Bononi, V.L.R. 2012. Xylophilous agaricomycetes (Basidiomycota) of the Brazilian Cerrado. Check List 8: 1102-1116.

Alexopoulos, C.J., Mims, C.W. \& Blackwell, M. 1996. Introductory Mycology. Wiley, New York.

Alvarenga, R.L.M., Naves, L.R.R. \& Xavier-Santos, S. 2015. The Genus Auricularia Bull. ex Juss. (Basidiomycota) in Cerrado (Brazilian Savanna) areas of Goiás state and the Federal District, Brazil. Mycosphere 6: 532-541. 
Araujo, A.S.F., Bezerra, W.M., Santos, V.M., Nunes, L.A.P.L., Lyra, M.C.C.P., Figueiredo, M.V.B. \& Melo, V.M.M. 2017. Fungal diversity in soils across a gradient of preserved Brazilian Cerrado. Journal of Microbiology 55: 273-279.

Baseia, I.G. 2005. Bovista (Lycoperdaceae): dois novos registros para o Brasil. Acta Botanica Brasilica 19: 899-903.

Baseia, I.G. \& Milanez, A.I. 2001a. Crucibulum laeve (Huds.) Kambly in cerrado vegetation of São Paulo State, Brazil. Acta Botanica Brasilica 15: 13-16.

Baseia, I.G. \& Milanez, A.I. 2001b. Nidularia pulvinata (Schwein.) Fries (Gasteromycetes): a new record from Brazil. Revista Brasileira de Botânica 24: 479-481.

Baseia, I.G. \& Milanez, A.I. 2002a. Montagnea haussknechtii Rab. (Podaxales) a rare agaricoid fungus: first record from Brazil. Acta Botanica Brasilica 16: 311-315.

Baseia, I.G. \& Milanez, A.I. 2002b. Tulostoma persoon (gasteromycetes) from the Cerrado region, State of São Paulo, Brazil. Acta Botanica Brasilica 16: 9-14.

Baseia, I.G. \& Milanez, A.I. 2003. Cyathus (Gasteromycetes) in areas of the Brazilian cerrado region, São Paulo State. Mycotaxon 80: 493-502.

Baseia, I.G., Silva, B.D.B., Leite, A.G. \& Maia, L.C. 2007. $\mathrm{O}$ gênero Calostoma (Boletales, Agaricomycetidae) em áreas de Cerrado e semi-árido no Brasil. Acta Botanica Brasilica 21: 277-280.

Blackwell, M. 2011. The fungi: 1, 2, 3.. 5.1 million species? American Journal of Botany 98: 426-438.

Bononi, V.L.R. 1984. Basidiomicetos do cerrado da Reserva Biológica de Moji-Guaçu, SP. Rickia 11: 1-25.

Borba-Silva, M.A., Drechsler-Santos, E.R. \& Robledo, G.L. 2015. Community structure and functional diversity of polypores (Basidiomycota) in the Atlantic Forest of Santa Catarina State, Brazil. Biotemas 28: 1-11.

Castro, A.P., Silva, M.R.S.S., Quirino, B.F., Bustamante, M.M.C. \& Krüger, R.H. 2016. Microbial Diversity in Cerrado Biome (Neotropical Savanna) Soils. PLoSONE 11: $\mathrm{e} 0148785$.

Clarke, K.R. \& Warwick, R.M. 1994. Change in Marine Communities: An Approach to Statistical Analysis and Interpretation, Natural Environment Research Council, United Kingdom.

Costa-Rezende, D.H., Ferreira-Lopes, V., SalvadorMontoya, C.A., Alves-Silva, G., Mello, A. \& Drechsler-Santos, E.R. 2015. New records of Perenniporia sensu lato and Pyrofomes for the Brazilian Cerrado. Iheringia 70: 157-166.

Coutinho, L.M. 2016. Biomas brasileiros. Oficina de Textos, São Paulo.
Dai, Y.C. 2012. Polypore diversity in China with an annotated checklist of Chinese polypores. Mycoscience 53: 49-80.

Eiten, G. 1994. Vegetação do Cerrado. In: M.N. Pinto (org.). Cerrado: Caracterização, Ocupação e Perspectivas. Editora Universidade de Brasília, Brasília, 2 ed, pp.17-73.

Fidalgo, O. \& Bononi, V.L.R. (org.). 1984. Técnicas de coleta, preservação e herborização de material botânico. Manual n. 4. Instituto de Botânica, São Paulo.

Fidalgo, O., Fidalgo, M.E.P.K. \& Furtado, J.S. 1965. Fungi of the "cerrado" region of São Paulo. Rickia 2: $55-71$.

Gibertoni, T.B., Santos, P.J.P. \& Cavalcanti, M.A.D.Q. 2007. Ecological aspects of Aphyllophorales in the Atlantic rain forest in northeast Brazil. Fungal Diversity 25: 49-67.

Gilbertson, R.L. 1980. Wood-rooting fungi of North America. Mycologia 72: 1-47.

Gilbertson, R.L. \& Ryvarden, L. 1986. North American Polypores. Fungiflora, Oslo, Norway.

Giudice-Neto, J.D. 2010. Plano de manejo integrado das unidades de conservação: Reserva Biológica e Estação Ecológica: Mogi-Guaçu, SP. Casa da Floresta, Piracicaba.

Gugliotta, A.M. 1997. Polyporaceae de Mata Ciliar da Estação Experimental e Reserva Biológica de MojiGuaçu, São Paulo, Brasil. Hoehnea 24: 89-106.

Gugliotta, A.M. \& Bononi, V.L.R. 1999. Polyporaceae do Parque Estadual da Ilha do Cardoso, São Paulo, Brasil. Boletim do Instituto de Botânica 12: 1-112.

Guzmán-Dávalos, L. \& Guzmán, G. 1979. Estudio ecológico comparativo entre los hongos (Macromicetos) de los bosques tropicales y los de coníferas del Sureste de México. Boletín de la Sociedad Mexicana de Micolgía 13: 89-125.

Hammer, Ø., Harper, D.A.T. \& Ryan, P.D. 2001. PAST: Paleontological Statistics. Software Package for Education and Data Analysis. Paleontologia Electronica 4: 1-9.

Hawksworth, D.L. \& Lücking, R. 2017. Fungal Diversity Revisited: 2.2 to 3.8 Million Species. 2017. Microbiology Spectrum 5: 1-17.

IBGE - Instituto Brasileiro de Geografia e Estatística. 2004. Mapa de Biomas e de Vegetação do Brasil. Available at https://biblioteca.ibge.gov.br/index.php/ biblioteca-catalogo? view $=$ detalhes $\&$ id $=66083$ (access in 08-V-2018).

Kirk, P.M., Cannon, P.F., Minter, D.W. \& Stalpers, J.A. 2008. Dictionary of the Fungi. 10 ed., CABI, Wallingford.

Klink, C.A. \& Machado, R.B. 2005. A conservação do Cerrado brasileiro. Megadiversidade 1: 147-155. 
Lindner, D.L., Burdsall, H.H. \& Stanosz, G.R. 2006. Species diversity of polyporoid and corticioid fungi in northern hardwood forests with differing management histories. Mycologia 98: 195-217.

Lundell, T.K., Mäkelä, M.R. \& Hildén, K. 2010. Ligninmodifying enzymes in filamentous basidiomycetes ecological, functional and phylogenetic review. Journal of Basic Microbiology 50: 5-20.

Maia, L.C., Carvalho Jr, A.A., Cavalcanti, L.D.H., Gugliotta, A.M., Drechsler-Santos, E.R., Santiago, A.L.M.A., Cáceres, M.E.S., Gibertoni, T.B., Aptroot, A., Giachini, A.J., Soares, A.M.S., Gomes-Silva, A.C., Magnago, A.C., Goto, B.T., Lira, C.R.S., Salvador-Montoya, C.A., Pires-Zottarelli, C.L.A., Silva, D.K.A., Soares, D.J., Rezende, D.H.C., Luz, E.D.M.N., Gumboski, E.L., Wartchow, F., Karstedt, F., Freire, F.M., Coutinho, F.P., Melo, G.S.N., Sotão, H.M.P., Baseia, I.G., Pereira, J., Oliveira, J.J.S., Souza, J.F., Bezerra, J.L., Araujo Neta, L.S., Pfenning, L.H., Gusmão, L.F.P., Neves, M.A., Capelari, M., Jaeger, M.C.W., Pulgarín, M.P., Menolli Jr, N., Medeiros, P.S., Friedrich, R.C.S., Chikowski, R.S., Pires, R.M., Melo, R.F., Silveira, R.M.B., Urrea-Valencia, S., Cortez, V.G. \& Silva, V.F. 2015. Diversity of brazilian fungi. Rodriguésia 66: 1033-1045.

Mantovani, W. \& Martins, F.R. 1993. Florística do cerrado na Reserva Biológica de Moji Guaçu, SP. Acta Botanica Brasilica 7: 33-60.

Nascimento, A.C., Gomes, E.P.C., Souza, J.I. \& PiresZottarelli, C.L.A. 2012. Zoosporic true fungi and heterotrophic straminipiles assemblages from soil of Brazilian Cerrado areas. Fungal Ecology 5: 114-123.

Núñez, M. 1996. Fructification of Polyporaceae s.l. (Basidiomycotina) along a gradient of altitude and humidity in the Guanacaste Conservation Area (Costa Rica). Journal of Tropical Ecology 12: 893-898.

Oliveira-Filho, A.T. \& Fontes, M.A.L. 2000. Patterns of Floristic Differentiation among Atlantic Forests in Southeastern Brazil and the Influence of Climate. Biotropica 32: 793-810.
Peel, M.C., Finlayson, B.L. \& McMahon, T.A. 2007. Updated world map of the Köppen-Geiger climate classification. Hydrology Earth System Science 11: 1633-1644.

Penttilä, R., Lindgren, M., Miettinen, O., Rita, H. \& Hanski, I. 2006. Consequences of forest fragmentation for polyporous fungi at two spatial scales. Oikos 114: 225-240.

Pereira, B.A.S., Venturoli, F. \& Carvalho, F.A. 2011. Florestas estacionais no Cerrado: uma visão geral. Pesquisa Agropecuária Tropical 41: 446-455.

Pivello, V.R. \& Coutinho, L.M. 1996. A qualitative successional model to assist in the management of Brazilian cerrados. Forest Ecology and Management 87: $127-138$.

Ryvarden, L. 1991. Genera of Polypores. Nomenclature and taxonomy. In: Synopsis Fungorum. Fungiflora, Oslo, Norway.

Ryvarden, L. 2004. Neotropical Polypores. Part 1. Introduction, Ganodermataceae \& Hymenochaetaceae. Synopsis Fungorum 19: 1-227.

Sampaio, A.J. 1916. A flora de Matto Grosso. Arquivos do Museu Nacional 19: 1-127.

Seibold, S., Bässler, C., Brandl, R., Gossner, M.M., Thorn, S., Ulyshen, M.D. \& Müller, J. 2015. Experimental studies of dead-wood biodiversity - A review identifying global gaps in knowledge. Biological Conservation 191: 139-149.

Teixeira, A.R. 1993. Chave para identificação dos gêneros de Polyporaceae com base na morfologia do basidioma. Boletim do Instituto de Botânica 8: 1-55.

Teixeira, A.R. 1994. Genera of Polyporaceae: an objective approach. Boletim da Chácara Botânica de Itu 1: 1-91.

Teixeira, A.R. 1995. Método para estudo das hifas do basidiocarpo de fungos poliporáceos. Manual n. 6 . Instituto de Botânica, São Paulo.

Tóthmérész, B. 1995. Comparison of different methods for diversity ordering. Journal of Vegetation Science 6: 283-290.

Zak, J.C. \& Willig, M.R. 2004. Fungal biodiversity patterns. In: G.M. Mueller, G.F. Bills, M.S. Foster (eds.). Biodiversity of Fungi: Inventory and Monitoring Methods. Elsevier Academic Press, San Diego, pp. 59-75. 